\title{
THE ROLE OF RURAL CITIES' FESTIVALS IN THE DEVELOPMENT OF REGIONS
}

\section{A VIDÉKI VÁROSOKBAN RENDEZETT FESZTIVÁLOK SZEREPE A RÉGIÓK FEJLŐDÉSÉBEN}

\author{
Katalin ÁSVÁNYI ${ }^{\mathrm{a}}$, Melinda JÁSZBERÉNYI ${ }^{\mathrm{b}}$ \\ ${ }^{a}$ Corvinus University of Budapest, 1093, Budapest, Fővám square 8., katalin.asvanyi@gmail.com \\ ${ }^{\mathrm{b}}$ Corvinus University of Budapest, 1093, Budapest, Fővám square 8., melinda.jaszberenyi@gmail.com
}

Cite this article: Ásvanyi, K., Jászberényi, M. (2017). The Role of Rural Cities' Festivals in the Development of Regions. Deturope, 9(3):177-187

\begin{abstract}
Festival tourism is a dynamically developing area of tourism which is supported by the growing number of festival tourists and by the strengthening of traveling motivations to festivals. The festivals have become very important attractions of the cities and regions. The number of rural cities' festivals which are mainly for the local communities, is growing by leaps and bounds, but the number of festivals specifically for tourists is also high. The tourist impacts of festivals could be analyzed at economical, physical, environmental, social and cultural levels, but the socio-cultural impact is an under-researched field. In this study we analyzed rural cities' festivals. We evaluated them on the basis of information available on their websites according to a predetermined criterion. The points of interest from the aspect of regional impacts were highlighted. Our research aims to show the best practices, so how the festival could attribute to the development of the regions.
\end{abstract}

Keywords: festival tourism, local community, regional cooperation

\begin{abstract}
A fesztiválturizmus egy dinamikusan fejlődő ágazata a turizmusnak, melyet a növekvő fesztivállátogatók száma és az ezen okból történő utazási motivációk erősödése is alátámaszt, valamint az egyes városok és régiók számára is egyre nagyobb vonzerőt jelentenek. A helyi közösségek számára megrendezett vidéki fesztiválok száma ugrásszerüen megnőtt, ugyanakkor a kifejezetten turisták számára létrehozott fesztiválok száma is magas. A fesztiválok turisztikai hatásait gazdasági, fizikai, környezeti, társadalmi és kulturális szinten is vizsgálható, azonban a társadalmi-kulturális hatásokat kevesen kutatják. Jelen tanulmányban vidéki városokban rendezett fesztiválokat vizsgáltunk, a honlapjaikon elérhető információk alapján értékeltük őket egy előre meghatározott szempontrendszer szerint, és rávilágítottunk a régiós hatások szempontjából sarkalatos pontokra. Kutatásunk célja a pozitív példák bemutatása, vagyis, hogy a fesztiválok milyen módon tudnak hozzájárulni a a régiók fejlődéséhez.
\end{abstract}

Keywords: fesztiválturizmus, helyi közösség, regionális együttműködés

\section{INTRODUCTION}

Festival tourism is one of the most dynamically growing areas of tourism. It is proved by the European Eurobarometer Committee's research which mentions the festivals as the 
motivation for travelling since 2009, and the festivals also mean a major attraction in destinations (IPK, 2008). The economic impacts of festivals have been researched since the 1960s, however, the sociocultural effects have not been analysed expect some research (Rátz, 1999; Kundi, 2013).

The aim of our research is to highlight the best practices of regional cooperation in festival tourism, and to examine how the festivals could contribute to the development of small and medium cities and also the region. In some cases negative impacts were also mentioned, but the positive examples were in the focus of our research. It was analysed by content analysis of the festivals' websites.

Our main research question was how the festivals could affect the locations directly, and how they could influence the regional development and cooperation.

\section{OBJECTIVES AND METHODS}

The relationship between festivals and tourism goes back for a long time. By the 21 st century these events became one of the most important forms of celebration culture (Szabó, 2012). Besides the events organized for the locals, recently the number of festivals aimed to target tourist has risen so much, it would be hard to keep count of them (Smith, 2009).

Many researchers examine the concept of festivals; nevertheless, there is not any definition which is commonly accepted. According to Getz (1997) the festival is identified as attraction, image builder, and the animator of static attractions and the catalyst of development. The definition of the Hungarian Festival Association has more concrete points: all the cultural, artistic, gastronomical, sport or other series of events could be named festivals which are themed (one or more themes, organized regularly in one or more locations, have a previously announced program and it aims to provide an experience that has high quality, transmits values an knowledge but also it is an enjoyable leisure social activity (Inkei, 2010).

According to the data from 2011 and 2014, art festivals are dominant in Hungary. The most common is to find festivals with a few thousands or a few 10 thousands visitors. The ration of foreigners decreases, which means that the festival tourism is becoming a more and more important motivational factor for travelling in the aspect of domestic tourism (Ásványi \& Márta, 2016).

The festivals aimed to target the local people, not tourists are important because of building communities and influencing on life quality. Organizing a festival could renew culture and/or strengthen local identity and acquiring facilities (organizing, cooperation), 
which could be very useful in the field of economic life (Smith, 2009). It is an interesting question that events meant to attract locals they have touristic significance or not (McKercher Mei, \& Tse, 2006).

It is quite common that a festival for locals is changed to be attractive for tourists as well. In this case, there could be problems about the loss of authenticity, the giving up of artistic value and the misesteem of culture (Smith, 2009). Meaning, the balance between the interest of the local community and the tourists is needed to find. The pressure of sponsors and mass tourism could also appear to be a danger factor, since it can make the festival one-sided. At the same time, the lack of tourist could cause the end of the event (Smith, 2009).

The location of the festival might be a critical point, as well as the handling of the development of such location. Due to the fact that mostly common areas give home the events, there is always a dependents relationship between the event and the authorities which leads to long licence procedures. The date changes also have the same critical characteristics which expect flexibility from the different stakeholders. Getz (1997) points out the difficulties of the negative image and successful management of publicity. He claims that a number of destinations do not recognize the benefits of festivals because of these failure factors (Getz, 1997) which cause economic unsustainability.

Although Tanford and Jung (2017) highlight that the satisfaction of the festival is strongly related to the loyalty which is important for the local community and also for the regional cooperation.

The festivals has a regional impact as create a positive image for the destination, stimulate the tourism demand, as more and more people come to the region because of festivals, so festivals could be tourism catalizator. These events also expand the tourist seasons, mainly if they are not in the summer. They also could enhance the life and pride of local community and people of the region, and they mean a way to reinforce social cohesion within the regional communities. (Akhoondnejad, 2016) Hjalager and Kwiatkowski (2017) analysed rural festivals in Denmark, so it can be claimed, that festivals have business opportunities for the region.

The effects of festivals could be examined in an economic, physical, environmental, social and cultural level. While the economic impact of festivals is a widely-researched area (Jászberényi, 2016), the socio-cultural effects are under-researched (Ásványi \& Jászberényi, 2017). 
The tourist arriving to the particular festival and destination, and the locals greeting them, and their relationship play an important role in the socio-cultural impact of festivals, and the touristic development of the destination also affects it (Kundi, 2013).

While examining the socio-cultural impacts, our aim was to demonstrate from the aspect of regional development, how the festivals could affect the locations directly, how they could influence the regional development and cooperation. As the focus was the social-cultural impacts, seven categories were used (Rátz, 1999) to analyse these regional aspects:

- the quality of locals' life,

- change and enlargement of employment structures,

- change of value-system

- development of individual, family and social relationship,

- expression of creativity,

- local community organizations,

- change and preservation of traditions.

While analysing these factors, the embeddedness to local communities was a key point, as the residents' participation in local festivals influence their quality of life and well-being (Yolal et al., 2016). In other words, what the locals' attitude is towards the festival, how much they support is, how much it means the possibility of preserving the local traditions and culture, how it contributes to the change of value-system, how it strengthens the family and social relations, how it helps the creativity and the organizations of the local community and how it changes the employment structure. All of the seven criteria from the regional point of view were examined and valued by the regional development and cooperation opportunities.

Our research was divided into two parts. The first phase of the research was made in a university course (Event management), Tourism and catering third year students (50 people) chose a festival and they interpreted the festival website along the seven criteria. The qualitative content analysis was used because it is a flexible research method to analyse documents and written materials (Babbie, 2003; Hoffman, Wilson, Martinez, \& Sailors, 2012). From festivals selected by the students 40 festivals' websites contain information for each criterion. Most of the information could be found in the news/information/archives part of the websites. In the second phase of our research these 40 festivals' websites were analysed. Content analysis were also conducted, in which the theoretical codes were determined along the seven criteria and the open codes were applied to highlight festivals' role in regional development. 
In our present research the social-cultural impacts of festivals were aimed to explore along the principles of regional development and cooperation. It was not our goal to generalize the results, but rather to highlight the positive examples.

\section{RESULTS}

Presenting the results of content analysis the dominant answers were highlighted along the seven criteria considering regional aspects.

In the respect of the quality of local life there are positive and negative impacts. The services improves and needs more and more, it is a good way for the local enterprises to show their products and services to people who do not meet them any other places, so the festivals are also a good chance to local and regional enterprises, they could come every year and it could serve them a current income in the days of the festivals. One of its main positive impacts is that festivals provide opportunities for regional cooperation. It also means over return for the settlement (village or town) which they can use for development and investment as Sopron does due to the Telekom Volt Festival. The festival is a good marketing tool for the settlements, it encourages their image and it can cause recreation for the city or the whole destination in the region. The festival warm the local people's life, it is a good way for relaxing and having fun, at the same time it also enhances the togetherness. Festivals invigorate the lives of local people; they give them entertainment and relax facilities, which good for social networking. In more festivals locals give accommodation for the guest of festivals, which can be a plus income, as Ördögkatlan Festival in Nagyharsány, more people have money to fuel due to the festival.

Although the festivals have negative impacts to the locals' lives. It causes loud noise, the settlement is dirty after the event, and it also destruct the environment. On the Komárom Days Festival (Komáromi Napok) year to year the organizers try to expand and make more beautiful the green areas of the city and before the festival they develop the physical environment of the event site as asphalting and renovating the buildings). During the festival the transportation is overcrowded and there are traffic jams, which makes locals's life harder in their every day, and also the capacity of the place of the settlement is not enough big for so many people. Now there are festivals which are outside the settlement to avoid this negative impact. For example the Voluta International Watercarneval (Voluta Nemzetközi Vízikarnevál) in Mosonmagyaróvár, which is outside the city, so it does not hold up the traffic and does not disturb the tranquillity of locals. To prevent or solve the negative impacts, it sometimes causes positive impact, as the Ozora Festival, where the environment awareness is 
an objective and verifiable as the area is clean and surprisingly high order and the slag material of the environmentally friendly flush toilets replaces about 80 percent of fertilizer used on the surrounding soil.

The impact on employment structure appears on more fields, the festivals have a bit more and deeper impacts for the settlement than for the region. The festivals cause positive impact on more industries, as they generate the tourism industry in the whole region; the accommodations are nearly $100 \%$ full of guests in the city and also in the settlements close to the festival, and hospitality also well-utilized during the festivals. A lot of local people are involved in the security service as in Fishing on Orfü. For local and regional businesses these festival days mean the biggest rate of the whole year income, as they could sell most of their products during the festivals. On the website of Szigliget Walleye festival (Szigligeti Süllőfesztivál), there are recommendations to catering, accommodations and wineries, and they employ local and regional handicrafts as the festival aims to extend the tourist season to boost local businesses. Local NGO-s (non-governmental organizations) could help more on festivals and could appear better, but rarely could we also find NGOs from the region. The big difference is in the permanent job, as for people from the region working on the festival it is only a seasonal job. In Savaria Historical Festival (Savária Történelmi Fesztivál) the number of permanent jobs also grows. Most of the festivals have volunteers especially students or retiring people as in Water-Music-Flower Festival (Víz-ZeneVirág Fesztivál), where also mainly due to the graduation requirement a lot of students volunteer at the event. The Győrkőc Festival also known as almost all the people who work there are volunteers. Being a volunteer in a festival is really important for locals, as it is a tradition in Hollókő Easter Festival. The festival also impact the employment structure geographically, as not just the local people, but also people from the region could show their products during the festival, as Vac Wordly Gaiety (Váci Világi Vigalom), where at first just the local residents sold their wares but now tradespeople come from all over the country.

The change of value system realizes from more aspects. Most of the festivals highlight the knowledge and love of the culture, which change people mind about the culture and show them how beautiful it could be There are values which promotes an approach to different ages, as the kid-centric Györkőc festival in Györ show that this type of events also can be a good relaxing program for kids not just for adults, and the family member can enjoy themselves together very well on festivals too. There are a lot of festivals where the guests can donate blood which raises awareness of the help of others as in Hungarikumok festival in Szeged where the opportunity of blood donation is given every day of the event. The festival also can serve others' help but in another way, as embracing young musicians. The Veszprém 
Street Music Festival (Veszprémi Utcazene Fesztivál) provides an opportunity both local, regional and other undiscovered young musicians to familiarize them. In the heart of the city there is space anywhere to play music. For locals the festival is particularly important, a large proportion of the population (mainly 15-30 years) participate in at least one day to see their friends' performance. The local identity is also a good value which can be strengthened by the festivals, and as it means local people like to live and work in their settlement and in their region. In the Szombathely Savaria Historical Festival (Szombathelyi Savária Történelmi Fesztivál) the local patriotism appears, people are proud of their city and worthy celebrate its creation. More and more festivals incite people to do sport activities. The Szeged Wine Festival organizes dragon boat race and half marathon. The values of gastronomy appear on festivals in several ways, for example Sweat Days in Győr (Édes Napok) we can see the countless ways of the use of chocolate. The Szigliget Walleye Festival draws the attention of the Hungarian wines, lake fiches and the importance of fish consumption. The environment and the awareness of environment as values can be found for example on Szeged Youth Days (SZIN-Szegedi Ifjúsági Napok), which also obtained the International Greener Festival Award.

The development of individual, family and social relationship can be experienced in every festival. The festivals could be family celebrations also, the locals invite their distant relatives and it strengthens the family relations. This type of event is also suitable for interacting people, people can have new friends, and they can be together on the festival next year or they can also meet other days of the year in the settlement. In Summerfest the locals have new friendship with foreigners too. Some people knew their love and come back later as a family, so children also will be traditional festival guests and for example on Szeged Youth Days (SZIN) there was a marriage proposal in 2015. On Beach Festival in Zamárdi (Strand Fesztivál) there are forums on website, where people can find a car, a free tent, almost everything, so anybody can go alone, he or she can be sure to find people with whom they can have fun. On Tokaj Wine Festival (Tokaji Borfesztivál) the leaders marching along with local people, they can have better relation, and people will be more loyal to the city. The residents of the surrounding settlements also know each other better, so for example The Pumpkin Festival (Tökfesztivál) has a strong community building impact in the region.

The expression of creativity could appear in three ways, as imaginative installations and works, as programs or in the field of gastronomy. One of the best example for creative installations on Volt Festival there is a Volt Art Zone, where in front of the eyes of the public they form furniture from pallet involving adventurous people. The programs are various in festivals, but the creative ones could be parades for example in baroque costume in Vác, or 
shows/exhibitions as falconer show and Old-timer exhibition in Hungarikumok. The creativity in gastronomy is expressed as interactive pastry making in Hugarikumok or cooking fish soup in a giant cauldron in International Tisza Fish Festival (Nemzetközi Tiszai Halfesztivál). The programs and gastronomy examples serve mainly the regional cooperation.

The local community organizations could be an important part of festivals, which is an essential element from regional aspect. Typically the following organizations participate as organizer in festivals: the local government, the local and regional NGOs, the educational institutions, the local and regional media-partners, the local and regional sponsors and wine makers. But there also organizations who are performers on the festival: local music groups and bands in classical and pop music, dance clubs and tradition preserving associations. Although there are organizations which are informal, just provide the opportunity for visitors to be together with the others: the blood donation in (Szekszárdi Szüreti Napok), the competitions as the Powerful Man Competition in, the parades in Pálinka and Little Pig Picnic in Zalaegerszeg (Pálinka and Mangalica Majális), and to collect donations as visitors could give donation in Szigliget Walley Festival to the SOS Kidvillage in Kecskemét.

The last criteria is to change and preserve the traditions. There are traditions related to gastronomy, folklore or culture. The main gastronomy traditions which appear on festivals are for example the gastrotours (wine, ramson), the cooking competitions, the pig slaughter, the vintage parade. There are folklore programs as folk bands or Swabia folk traditions and other authentic programs. We can meet cultural or historical programs which also preserve traditions as archery and horse-riding program in Water-Music-Flower Festival or the baroques parade.

As the analysed festivals is organized since more years, the locals and people from the region is waiting and preparing for it, and they make inquiries about the program and tickets, it is really important from the social sustainability part. Most of the time the festival mean the primary income for locals and local enterprises in the summer as locals could give guests accommodation and SMEs (small and medium enterprises) realize their products and services which encourages the regional development economically.

\section{DISCUSSION AND CONCLUSION}

Analysing the socio-cultural impacts of festivals, we highlighted the main actors and the fields in which the regional development and cooperation could implemented due to the festivals: services, tourism, marketing, economy and society. 
For local and regional enterprises the festivals could be a very good opportunity to show their products and services. People from the region could meet them and buy from them. The festivals also give chance for local and regional NGOs, they can appear with a stand and people get know their activities. Regional bands could play music and get more audience. Dance club could dance and people from the region might take a fancy to join to the club. Due to the festivals there is a growing demand to the private and commercial accommodations and also the restaurants and other hospitality service suppliers. These days are the most reserved days of the year for the accommodations in the festival cities and also in the surrounding settlements.

As social impact the festivals facilitate the community building of the region, people get know each other. The surrounding settlements work and entertain together. As local communities like to live in their region, they will not move anywhere, they want to work and live in their region.

There are also some economic impacts which help the regional development. Due to the plus income which realized in the cities and the regions, there are more infrastructural developments and investments. The region could be attractive to new investors and companies, so the positive effects could be realized in regional level.

From the marketing aspect the festivals rise the image of the city and the region, it is good for revitalize the destinations and the whole region might became well-known.

Our main research question could be answered by the results of content analysis. The festivals mainly have positive impacts on the locations, and they could also positively influence the regional development and cooperation so we could claim that the festival tourism is a good chance to regional cooperation and development on more levels.

However, the festivals also raise a number of dilemmas. The internationalizations and the continuous increase in the number of visitors might affect the loss of authenticity and culture, and the abandonment of the art fair. These priorities are hard to be reconciled as the aim of the analysed festivals is to preserve tradition by involving the local community and also attracting tourists. There are further research fields in this topic such as the effect of increase in' number visitors for authenticity or the change in relationship between local inhabitants and tourists which also influence the regional impact of the festivals.

\section{REFERENCES}

Akhoondnejad, A. (2016). Tourist loyalty to a local cultural event: The case of Turkmen handicrafts festival, Tourism Management, 52, 468-477. 
Ásványi, K., \& Jászberényi, D. (2017). The effects of the festivals in the light of sustainability, Sustaining sustainabilities - Tourism 2017, cultural heritage and cultural capital, Conference proceeding, Veszprém, 3th- $6^{\text {th }}$, May, 2017 ((in press))

Ásványi, K., \& Márta, I. (2016). VI. A hazai fesztiválpiac kínálata [The supply of the Hungarian festivals], in: Jászberényi, M. - Zátori, A. - Ásványi, K. (szerk). Fesztiválturizmus (Festivaltourism), Akadémia Kiadó, Budapest. 82-96.

Babbie, E. (2003). A társadalomtudományi kutatás gyakorlata. [The practice of social science research] Balassi Kiadó: Budapest.

Getz, D. (1997). Event Management and Event Tourism. Cognizant Communications Cororations, New York.

Golnhofer, E. (2001). Az esettanulmány. [The case study] Müszaki Kvk., Budapest

Hjalager, A. \& Kwiatkowski, G. (2017). Entrepreneurial implications, prospects and dilemmas in rural festivals, Journal of Rural Studies, in Press

Hoffman, J.V., Wilson, M.B., Martinez, R.A., \& Sailors, M. (2012). Content analysis: The past, present, and future. In: Duke, N., \& Mallette, M. (Eds.). Literacy Research Methodologies, Second Edition New York: Guilford, 28-49.

Inkei, P. (2010). A magyarországi fesztiválok minösitési rendszere. [The qualification system of Hungarian Festivals] Magyar Fesztivál Regisztrációs és Minősítési program füzet., Budapest. 2010

IPK (2008). European Travel Monitor 2008, IPK International, Munich

Jászberényi, M. (2016). II. A fesztiválok gazdasági hatása [The economic impact of festivals], in: Jászberényi, M. Zátori, A., \& Ásványi, K. (szerk). Fesztiválturizmus, Akadémia Kiadó, Budapest. 34-43.

Kundi, V. (2013). Fesztiválok városokra gyakorolt gazdasági és társadalmi-kulturális hatásainak elemzése, A györi Magyar Táncfesztivál és a Miskolci Operafesztivál példáján keresztül [The analysis of economic and socio-cultural impacts of festivals, The Hungarian Dance festival in Györ and the Miskolc Opera festival], PhD disszertáció, Győr.

McKercher, B., Mei, W.S., \& Tse, T.S.M. (2006). Are Short Duration Cultural Festivals Tourist Attractions? Journal of Sustainable Tourism, 2006/1, 55-66.

Rátz, T. (1999). A turizmus társadalmi-kulturális hatásai [The socio-cultural impacts of tourism], PhD disszertáció, Budapesti Közgazdaságtudományi Egyetem, Budapest.

Smith, M. (2009). Fesztiválok és turizmus. Lehetőségek és konfliktusok. (Festivals and tourism. Opportunities and conflicts). Turizmus Bulletin, 2009/3. Budapest.23-27.

Szabó, J.Z. (2012). A turisztikai fesztiválok látogató-összetétele. [The visitors of touristiv festivals] In: Juhász, E. - Chrappán, M (szerk.) (2012). Tanulás és müvelödés, Debrecen: Debreceni Egyetem. 535-540.

Tanford, S., \& Jung, S. (2017). festival attributes and perceptions: A meta-analysis of relationships with satisfaction and loyalty, Tourism Management, 61, 209-220 (in press)

Yolal, M., Gursoy, D., Uysal, M., Kim, H., \& Karacaoglu, S. (2016). Impacts of festivals and events on residents' well-being, Annals of Tourism Research, 61, 1-18.

Annex 1 Analysed websites (Download in March-May 2016):

\begin{tabular}{|c|c|}
\hline 1. Badacsonyi borhetek & $\begin{array}{l}\text { http://www.badacsony.com/esemenyek/badacsonyi- } \\
\text { borhetek-201107160731.html }\end{array}$ \\
\hline 2. Balaton Sound & http://sziget.hu/balatonsound/ \\
\hline 3. Bánkitó Fesztivál & http://bankitofesztival.hu/?lang=en \\
\hline 4. Barokk Esküvő & $\begin{array}{l}\text { http://www.mufegyor.hu/hu/esemenyek/25-barokk- } \\
\text { eskuvo }\end{array}$ \\
\hline 5. Boglári Szüreti fesztivál & http://www.boglariszuret.hu \\
\hline
\end{tabular}




\begin{tabular}{|c|c|}
\hline 6. Debreceni Campus Fesztivál & http://www.campusfesztival.hu/ \\
\hline 7. DUDIK & http://dudik.hu/ \\
\hline 8. Dunakeszi Feszt & http://www.dunakeszifeszt.hu/ \\
\hline 9. Édes Napok - Győr & http://edesnapok.hu/gyor-2017/ \\
\hline 10. Efott & http://efott.hu/ \\
\hline 11. Egerszeg Fesztivál & https://www.egerszegfesztival.hu/ \\
\hline 12. Egri Bikavér Ünnep & http://www.bikaverunnep.hu/ \\
\hline 13. Fehérvári Lecsófőző Vígazság & http://www.fehervarilecso.hu/ \\
\hline 14. Fishing On Orfü & http://www.fishingonorfu.hu/ \\
\hline 15. Győrkőc Fesztivál, Győr & http://www.gyorkoc.hu/ \\
\hline 16. Gyulai Kolbász-és Sódarmustra & http://www.sodarmustra.hu/ \\
\hline 17. Komáromi Napok & http://komarominapok.eu/ \\
\hline 18. Közgáz évzáró & http://evzaro.kozgaz.net/ \\
\hline 19. MEN & http://www.mehok.uni-miskolc.hu/men/ \\
\hline 20. Mohácsi Busójárás & http://www.mohacsibusojaras.hu/ \\
\hline 21. Nagymarosi Sváb-és Szüreti fesztivál & http://www.nagymaros.hu/ \\
\hline 22. Ozora Fesztivál, Dádpuszta & https://ozorafestival.eu/ \\
\hline 23. Örségi Tökfesztivál & http://www.orsegitokfesztival.hu/ \\
\hline $\begin{array}{l}\text { 24. Pálinka és Mangalica Majális - } \\
\text { Zalaegerszeg }\end{array}$ & http://zgke.hu/majalis/ \\
\hline 25. PEN & http://www.pecsiegyeteminapok.com/ \\
\hline $\begin{array}{l}\text { 26. Savaria Történelmi Fesztivál, } \\
\text { Szombathely }\end{array}$ & http://www.karnevalsavaria.hu/2017/ \\
\hline 27. Strand Fesztivál & http://strandfesztival.com/ \\
\hline 28. Summerfest & https://summerfest.com/ \\
\hline 29. Szegedi Borfesztivál & http://szegediborfesztival.hu/ \\
\hline 30. Szegedi Hungarikumok Fesztivál & http://hungarikum-fesztival.hu/ \\
\hline $\begin{array}{l}\text { 31. Szegedi Nemzetközi Tiszai } \\
\text { Halfesztivál }\end{array}$ & http://www.halfesztival.szegedihalaszcsarda.hu/ \\
\hline 32. Szekszárdi szüreti fesztivál & $\begin{array}{l}\text { http://www.szekszardiszuretinapok.hu/index.php?acti } \\
\text { on=kezdolap }\end{array}$ \\
\hline 33. Szigligeti süllőfesztivál & http://www.sullofesztival.hu/ \\
\hline 34. SZIN & http://szin.org/ \\
\hline 35. Tokaji Borfesztivál & http://www.tokaj-turizmus.hu/Tokaji-Bornapok \\
\hline 36. Váci Világi Vigalom & http://vacivigalom.hu/ \\
\hline $\begin{array}{l}\text { 37. Veszprémi Utcazene Fesztivál, } \\
\text { Veszprém }\end{array}$ & http://www.utcazene.hu/ \\
\hline 38. Víz-zene-virág Fesztivál & http://vizzenevirag.hu/ \\
\hline 39. VOLT Fesztivál & http://volt.hu/ \\
\hline $\begin{array}{l}\text { 40. Voluta Nemzetközi Vízikarnevál, } \\
\text { Mosonmagyaróvár }\end{array}$ & http://www.voluta.hu/ \\
\hline
\end{tabular}

